\title{
Assessing Livelihood Vulnerability to Climate Change Based on Livelihood Zone: Evidence from Mixed Farming System in Kembata Tembaro Zone, Southern Ethiopia
}

\author{
Authors: Yohannes P. ${ }^{1} \quad$ Ali H. $^{2} \quad$ Teshale W. $^{3} \quad$ Abate M. ${ }^{4}$ \\ 1.College of Development Studies, Addis Ababa University, P.O. Box 21514/1000, Addis Ababa, Ethiopia. \\ 2.College of Development Studies, Center for Rural Development, Addis Ababa University \\ 3.Hawassa Univeristy, Wondo Genet College of Forestry and Natural Resources, P. O. Box 128, \\ Shashemene, Ethiopia. \\ 4.College of Development Studies, Center for Rural Development, Addis Ababa University
}

\begin{abstract}
Climate change vulnerability depends upon various factors and differs between places, sectors and communities. This study is aimed at analyzing smallholder farmers' livelihood vulnerability to climate change and variability in Kembatta Tembaro zone, Southern Ethiopia using the IPCC Livelihood Vulnerability Index approach. The approach estimates vulnerabilities by grouping nine major components into three categories of exposure, sensitivity and adaptive capacity, using data collected from 508 randomly selected farm households based on five livelihood zones. The result score of Livelihood Vulnerability Index revealed that Coffee livelihood zone with high exposure index coupled with limited adaptive capacity made it the most vulnerable among the five livelihood zones; whereas, Ginger livelihood zone with very high adaptive capacity index and low sensitivity, coupled with medium level exposure index to climate change has greatly contributed for its least vulnerability score. In line with the results, people-centered strengthening of adaptive capacity based on the local geographical and socio-economic profiles as well as widening opportunities for off-farm livelihood strategies is essential.
\end{abstract}

Keywords: Climate Change, Livelihood Zone, Livelihood Vulnerability

DOI: $10.7176 / \mathrm{JEES} / 9-6-06$

Publication date:June $30^{\text {th }} 2019$

\section{Introduction}

Recently, climate change has become one of the most urgent challenges for today's society that seeks an integrated effort at all levels and sectors, as it is linked with the day to day livelihood systems of billions of people. The impact on each region depends mainly on the degree of vulnerability that natural ecosystems and human-made infrastructure have to changes in climate and extreme meteorological events, as well as on the coping and adaptation capacity towards new environmental conditions. Many areas in Africa are recognized as having climates that are among the most variable in the world on seasonal and decadal time scales. It is because of this reality that Africa has been identified as one of the parts of the world most vulnerable to the impacts of climate change (IPCC, 2014; Niang et.al., 2014).

Sub-Saharan Africa is vulnerable to climate change for a couple of facts inherent in the region; high natural resource and agricultural dependence; poverty (58.9\% living under multi-dimensional poverty (Alkire and Housseini, 2014); inadequate and ailing infrastructure; structural challenges at policy level (Ondige et al., 2013) and limited access and use of relevant and reliable agricultural inputs (Ringler et al., 2010).

Ethiopia belongs to countries with high and stable vulnerable countries in the world. Reasons for Ethiopia's vulnerability are manifold. Adenew, (2006) states that Ethiopia's geographical location and topography, plus a low adaptive capacity make the country highly vulnerable to the adverse impacts of climate change. Recently, there is an increasing interest in using livelihoods analysis as a 'lens' through which to view a number of subjects. These subjects range from emergency response to disaster mitigation to longer term development. In order to study vulnerability and adaptation strategies of smallholder farmers to climate change, first, it is very important to identify the livelihood system of those farmers, as the concept of vulnerability is dynamic, context specific and multidimensional in nature. An understanding of people's livelihoods is essential for analysing the impact of any significant change. Seamana et.al., (2014) indicated that livelihood-based approach provides logic to know livelihoods, how they are affected by changes and shocks, and how households cope and adapt with the challenges to reduce vulnerability.

In Ethiopian context, climatic heterogeneity is a hallmark of the country, altitude determining the distribution of climatic factors (temperature and rainfall) and land suitability; and influences the crops grown, the rate of crop growth, and the natural vegetation types and their species diversity. This reality leads to have different livelihood systems across different regions and subsequent zones in the country. In describing livelihood and resilience terms, it is important to view and describe from the context of Livelihood Zone boundaries. According to FAO and ILO (2009), livelihood zones refer to zones within which people share broadly the same production system and common 
livelihood sustaining activities and goals. The livelihood zones are based on economic geography rather than administrative divisions and are the final results of a combination of geographic factors, like altitude, rainfall, and population density, as well as market forces (DRMFSS, 2010). According to the livelihood zone classification, there are 175 different livelihood zones in Ethiopia and 40 in SNNPR (ibid). The study area covers five livelihood zones. The degrees, therefore, of vulnerabilities to climate change of different livelihood zones and farming systems vary accordingly. This calls for the need to raise livelihood zone based systematic inquiry of analyzing vulnerability of smallholder farmers' to climate change. This study, therefore, fill the knowledge gap by analyzing vulnerability of smallholder farmers' to climate change based on livelihood zone approach in Kembatta Tembaro zone, southern Ethiopia.

\section{Research Question}

This paper answers the following research questions:

$>$ To what extents are smallholder farmers vulnerable to climate change and what factors influenced their vulnerability in the study area?

$>$ What are the constraints that exacerbate vulnerability of households in different livelihood zones?

$>$ What are the sources of livelihood vulnerability to climate change?

\section{Methods and Materials}

\subsection{Description of the Study Area}

The study was conducted in Kembata Tembaro Zone, which is located in Southern Nations, Nationalities, and Peoples' Region (SNNPR) of Ethiopia. According to CSA (2013), the study area is projected to have a population size of 902,073 by the end of 2017 , of which 442,883 are male and 459,190 are female. As a result, the study area belongs to one of the most densely settled areas in Ethiopia, with a population density of 665 per square kilometre, much higher than the estimated regional average of 164 (ibid).

In this study, Sustainable Livelihood Approaches (SLA) has been adapted to contextualize the social, geographical and economic situations of the study communities. It is known that the application of sustainable livelihood approach is flexible and adaptable to specific local settings and the objectives defined. Accordingly, the study used livelihood zone approach to further analyze the levels of smallholder farmers' adaptive capacity. According to the livelihoods zone classification, there are 175 different livelihood zones in Ethiopia, out of this 40 are found in SNNPR (DRMFSS, 2010). The study area covers five main livelihood zones, namely; Kambata Cereal and Enset LZ, Badewacho-Alaba Maize LZ, Hadero-Ginger LZ, Alaba-Mareko Lowland Pepper LZ and Kedida-Badewacho Coffee LZs (DPPC 2005b).

Table 1: Description of Livelihood Zones (LZs)
Livelihood Zone
Altitude Range
Major Crops Grown
Location

(masl)

\begin{tabular}{|c|c|c|c|}
\hline Kembata Cereal and Enset LZ & $2200-3028$ & $\begin{array}{l}\text { False banana, Wheat, Barely, } \\
\text { Beans, Peas, etc }\end{array}$ & North West \\
\hline Kedida-Badewacho Coffee LZ & $1900-2200$ & Coffee, False banana, Taro, etc & $\begin{array}{c}\text { South } \\
\text { Central }\end{array}$ \\
\hline Hadero-Ginger $\mathbf{L Z}$ & $1500-2100$ & $\begin{array}{l}\text { Ginger, False banana, Banana, } \\
\text { Avocado, etc }\end{array}$ & South West \\
\hline $\begin{array}{l}\text { Badewacho-Alaba Maize LZ } \\
\text { Alaba-Mareko Lowland Pepper LZ }\end{array}$ & $\begin{array}{l}1400-1800 \\
1600-1800\end{array}$ & $\begin{array}{l}\text { Maize, Teff, Soybean, Millet, etc } \\
\text { Pepper, Millet, Sorghum,etc }\end{array}$ & $\begin{array}{l}\text { South East } \\
\text { North East }\end{array}$ \\
\hline
\end{tabular}




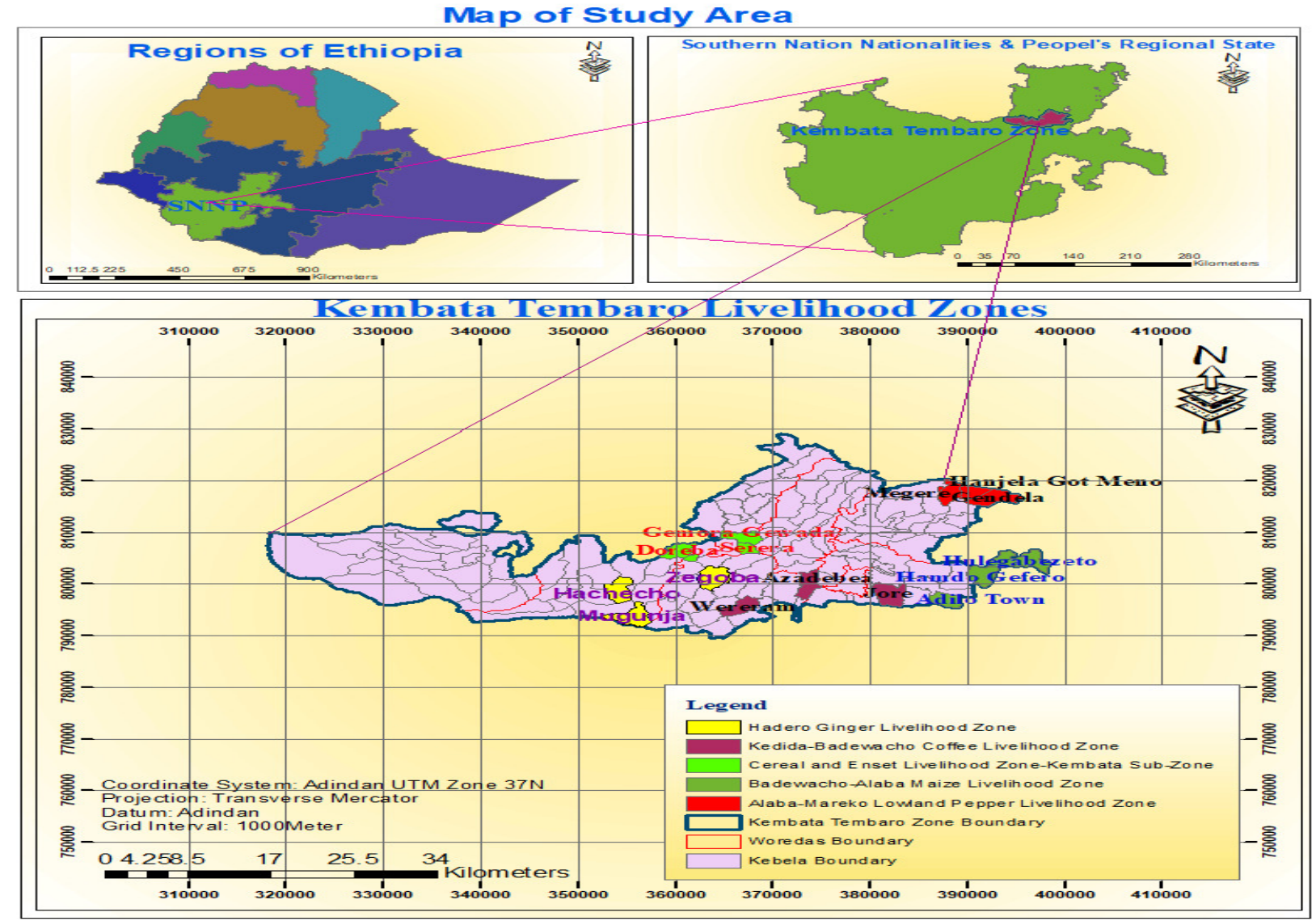

Figure 1: Map of the study area

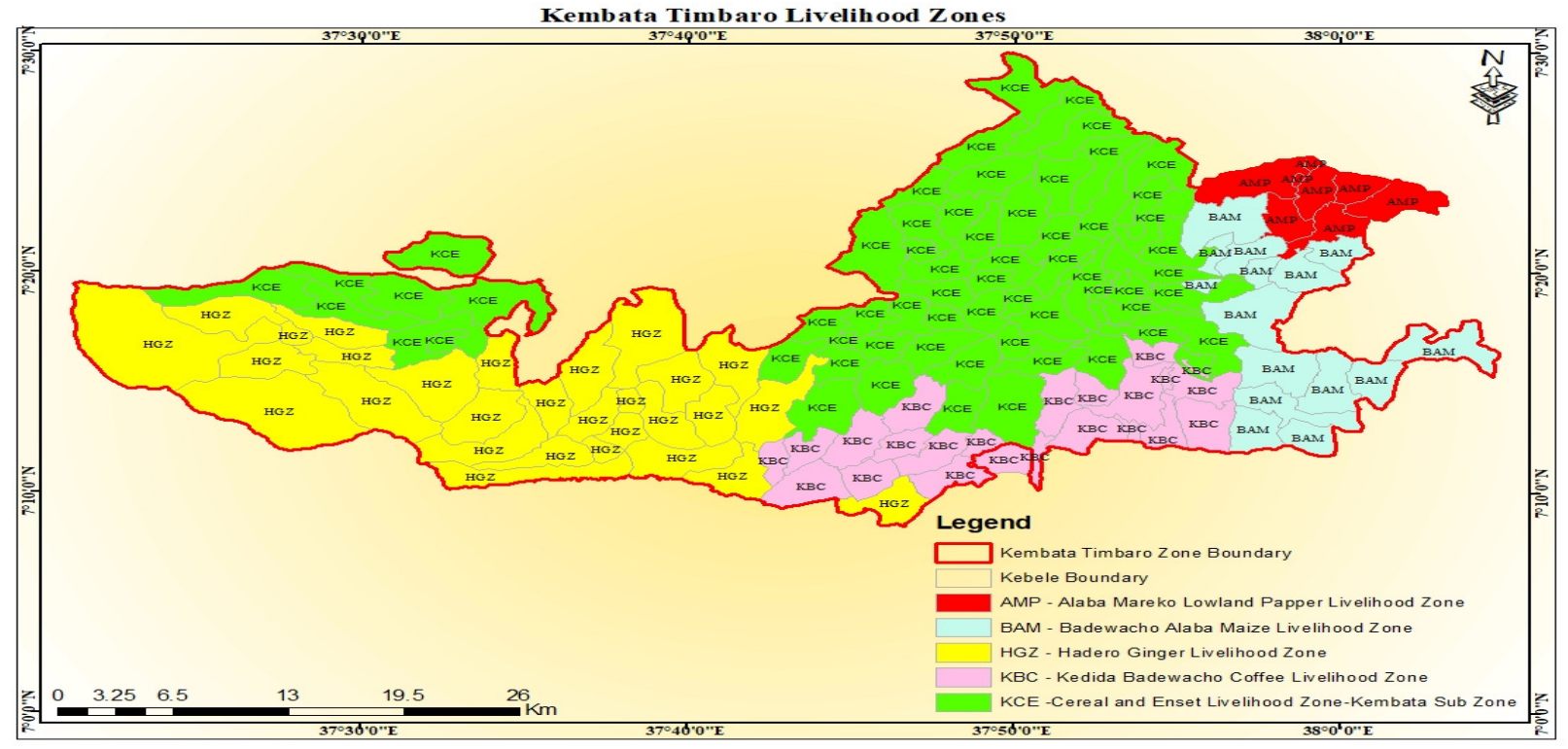

Figure 2: Map of the Study Area Based on Livelihood Zone Classification

Source: Own construct

\section{Research Design}

\subsection{Data Sources and Methods of Data Collection}

The data for this study were collected from both primary and secondary sources. Household survey questionnaires, focus group discussions and field observation were the primary data sources and zonal and district level reports were secondary sources used from the respective Agriculture and Natural Resources Offices. Overall, a cross 
sectional household survey composed of both qualitative and quantitative methods was carried out using a standard structured questionnaire of both close and open ended types of questions. Through the questionnaire, farmers were asked to provide information on socio-economic characteristics, vulnerability contexts, LULCC trends, livelihood assets, climate change perceptions, adaptation and coping strategies and also institutional access and capacities.

\subsection{Target Population and Sampling Technique}

The target population of the study was smallholder farmers engaged in agricultural activities across five livelihood zones in Kembata Tembaro zone. In terms of administrative units, the study area comprised of seven districts, namely, Kedida Gamela, Kacha Bira, Angacha, Danboya, Hadero-Tunto, Tembaro and Doyogena. However, it is difficult to divide the districts proportionally to each livelihood zones, as livelihood zones do not normally follow the formal administrative boundaries. Out of the total of seven districts, five districts, namely; Doyogena, Kachabira, Hadero-Tunto, Kedida Gamela and Damboya are purposefully selected, based on representation of the typical livelihood zone settings, demographic and socio-economic attributes, geographical characteristics and previous history of the occurrence and impact of climate change (including the last three drought years). In order to determine the sample size of households, the formula set by Kotari $(2004$, p. 179) in the case of finite population was used and 508 farm households were randomly drawn from the selected kebeles, using the formula:

$$
\mathrm{n}=\frac{z^{2} * p * q * N}{e^{2}(\mathrm{~N}-1)+\mathrm{z}^{2} * \mathrm{p} * \mathrm{q}}
$$

\subsection{Data Analysis Techniques}

The formulation for Livelihood Vulnerability Index (LVI) developed for this study is based on the livelihood vulnerability analysis technique developed by Hahn et.al., (2009), with replacements of some indicators to suit the local context of the study area. It makes use of nine major components, namely; Natural Disaster, Assets and Basic Services, Land and Water, Nutrition and Health, Skill and Knowledge, Socio-economic, Biophysical, Social and Institutional and Finance and Incomes (See Annex). First, each of the sub-components is measured on a different scale and finally description of the aggregate level of the degree of vulnerability of the study area was given. Since each of the sub-components is measured on a different scale, it is first necessary to standardize each as an index as:

$$
\begin{aligned}
& \text { index }_{S L Z}=\frac{S_{L Z}-S_{\text {min }}}{S_{\text {max }}-S_{\text {min }}} \\
& \text { Equation (1) }
\end{aligned}
$$

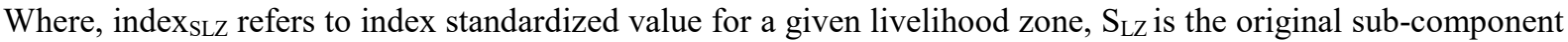
for a given livelihood zone, and $S_{\min }$ and $S_{\max }$ are the minimum and maximum values respectively for each subcomponent. After each is standardized, the sub-components were further averaged using equation (2) to calculate the value of each major component:

$$
M_{L Z}=\frac{\sum_{n i=1} \text { index }_{S L Z} \dddot{Z}_{i}}{n}
$$

Where, $\mathrm{M}_{\mathrm{LZ}}$ is one of the nine major components for Livelihood Zone, index $\mathrm{SLZi}_{\mathrm{Z}}$ represents the sub-components indexed by $i$, that make up each major component and $n$ is the number of sub-components in each major component. Once, values for each of the nine major components for the Livelihood Zones are calculated, major components that make up each livelihood assets is averaged using the following equation (3) to obtain the Livelihood Vulnerability Index at Livelihood Zone level:

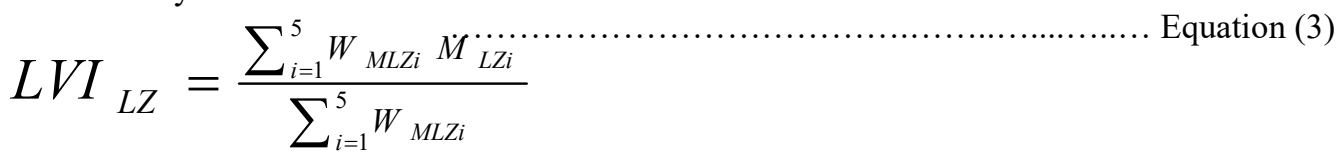

Which can be expressed as:

$$
L V I_{L Z}=\frac{W_{H} H_{L Z}+W_{N} N_{L Z}+W_{S} S_{L Z}+W_{p} P_{L Z}+W_{F} F_{L Z}}{W_{H^{+}}+W_{N}+W_{S}+W_{P}+W_{F}}
$$

Where, LVILz: is the vulnerability index for one of the five livelihood assets of livelihood zone LZ, equals the weighted average of major components which form that livelihood asset; WMLz: the weights of each major component, are determined by the number of sub-components that makeup each major capital. Calculating the LVI-IPCC is an alternative method for calculating LVI that incorporates the IPCC vulnerability which is used by Hahn, et.al., (2009). The LVI-IPCC diverges from LVI when the major components are combined. They are combined using the following equation; 


$$
C F_{L Z}=\frac{\sum_{i=1}^{n} W_{M L Z i} M_{L Z i}}{\sum_{i=1}^{n} W_{m L Z i}}
$$

Equation (4)

Where, $\mathrm{CF}_{\mathrm{LZ}}$ is an IPCC defined contributing factor (i.e. Exposure, Sensitivity, or Adaptive Capacity) for Livelihood Zone LZ, $\mathrm{W}_{\mathrm{MLZi}}$ is the weight of each major component, and $\mathrm{M}_{\mathrm{LZi}}$ are major components for livelihood zone LZ, indexed by $i$, and $n$ is the number of major components in each contributing factor. Once, exposure, sensitivity and adaptive capacity are calculated, the three contributing factors will be combined using the formula developed by Hahn et.al., (2009):

$$
\text { ............................................... Equation (5) }
$$

$$
L V I-I P C C_{L Z}=\left(e_{L Z}-a_{L Z}\right) * S_{L Z}
$$

Where, $L V I-I P C C_{L Z}$ is the LVI for livelihood zone LZ, expressed using the IPCC vulnerability framework, $\boldsymbol{e}$ is the calculated exposure score for livelihood zone LZ, $\boldsymbol{a}$ is the calculated adaptive capacity score for livelihood zone LZ, and $\boldsymbol{S}$ is the calculated sensitivity score for livelihood zone LZ. And then the LVI-IPCC is scaled from 1 (denoting least vulnerable) to 1 (Denoting most vulnerable).

\section{Results and Discussion}

Table 2: Major Components of LVI

\begin{tabular}{|l|l|l|l|l|l|}
\hline Major Component/s & CELZ & CLZ & GLZ & MLZ & PLZ \\
\hline Natural Disaster & 0.574 & 0.481 & 0.502 & 0.492 & 0.465 \\
\hline Assets and Basic Services & 0.331 & 0.429 & 0.383 & 0.327 & 0.316 \\
\hline Land and Water & 0.478 & 0.507 & 0.470 & 0.529 & 0.493 \\
\hline Nutrition and Health & 0.148 & 0.385 & 0.349 & 0.384 & 0.365 \\
\hline Skill and Knowledge & 0.593 & 0.535 & 0.546 & 0.518 & 0.496 \\
\hline Socio-economic & 0.291 & 0.313 & 0.372 & 0.354 & 0.287 \\
\hline Biophysical & 0.387 & 0.410 & 0.343 & 0.419 & 0.427 \\
\hline Social and Institutional & 0.402 & 0.314 & 0.377 & 0.286 & 0.334 \\
\hline Finance and Incomes & 0.305 & 0.276 & 0.334 & 0.247 & 0.255 \\
\hline
\end{tabular}

Source: Household survey

The result revealed that Cereal LZ has the highest value of Natural Disaster (0.574), which is one of the influencing factors, in addition to Infrastructure, Assets and Services for exposure of farmers to climate change. In addition, the LZ has also the highest score in Skill and Knowledge (0.593) and Social and Institutional components (0.402); indicating with relatively better access to social membership, cultural connectivity, local institutional support, access to indigenous knowledge and trust and mutual support, which contributes for its higher adaptive capacity.

On the other hand, Cereal and Enset LZ registered the least score of Nutrition and Health (0.148), indicating farmers have less access to food and health. In terms of Skill and Knowledge, Pepper LZ has the least result $(0.496)$ indicating that the LZ has relatively scored less in educational attainment, skill and knowledge and technology adoption. In terms of Biophysical assets, Pepper LZ has the highest score (0.427) indicating that the LZ registered better result in land protected from degradation, and having suitable slope (topography) of cultivated land. It is noted that Pepper LZ has the highest farm land size as compared with all LZs.

Having the highest human capital is critical in terms of building the adaptive capacity of farmers in the LZ. In the context of Assets and Basic Services, Coffee LZ has the highest result (0.429), for which access to off-farm activities contribute for registering higher assets, which helps to reduce vulnerability to climate change. With respect to Land and Water, which is the most critical component for sensitivity in all LZs, the least result is found in Ginger LZ (0.470), as there is the least farm size among the five LZs and the highest household size, which can contribute for higher sensitive to climate change.

Socio-economically, including farming experience and dependency ratio, Ginger LZ $(0.372)$ has the highest result which can contribute for higher adaptive capacity. With regards to Assets and Basic Services, including livestock ownership, access to all weather roads, and access to veterinary services, Coffee LZ (0.429) has the highest result. This leads us to state that cash crop areas agro-ecologically located in midland areas have better result in socio-economically and having better assets and services, indicating that comparatively contributing for higher adaptive capacity. In addition, Ginger LZ has the highest result in terms of Finance and Incomes (0.334), for which the cash crop Ginger has contributed a lot, as the crop currently has higher market value, hence, influencing income from agriculture.

Better access to infrastructure, assets and basic services play critical role in reducing exposure of smallholder 
farmers to climate change. The highest score is registered in Coffee LZ (0.429), indicating that the LZ has better access to roads, access to climate information, type of house, ownership of pack animals and access to veterinary services; whereas Pepper LZ has the least score (0.316), indicating that the above assets and basic services are less owned and accessed for farmers, increasing their vulnerability to climate change.

The other component of LVI analyzed is access to land and water, which fall under sensitivity. It is beyond despite that land is the main source of livelihood, which has social, economic, and cultural values in smallholder agricultural livelihood system. If properly used and endowed with higher productivity and accessed with water, is capable of contributing greatly in reducing vulnerability to climate change. The analysis revealed that Maize LZ has the highest score of land and water, 0.529, indicating that the livelihood zone has better land productivity (which the flat topography of the land mainly contributes), better access to grazing land, as the livelihood zone has the second highest land size per household next to Pepper LZ, with 0.652 ha, and better access to animal forage have contributed for its highest score. On the other hand, Ginger LZ has the lowest score in Land and Water component, (0.470), indicating that it has the least average land size, 0.349 ha per household and with the highest household size of about 10 persons, which contributed for its least land holding size per household. In addition, with the continuous cultivation of the land, the productivity gets less from year to year, less access to grazing land and animal forage, which have contributed for the least score.

Among the nine components pertinent to indicate the level of vulnerability to climate change in the context of livelihood zones is socio-economic. In the assessment of sub-indicators selected for socio-economic profile is farming experience, dependency ratio and access to off-farm activity. The result revealed that Ginger LZ has the highest score, 0.372, whereas, Pepper LZ has the least score, 0.287, as compared with the five LZs. Specifically access to off-farm activity is better accessed for farmers in Ginger LZ as the livelihood zone has the highest family size of about 10. In addition, Ginger LZ has better access to small markets and towns in the nearby kebeles and the current higher market value of ginger as compared with pepper. Large family size is assumed to be the source of labor, skills and strong social capital to adapt to changing climate situation (Deressa et al., 2011) and enable a household to accomplish various agricultural tasks especially at the peak seasons.

Access to Finance and Incomes is an important indicator of vulnerability status of households, which is represented in this study through access to credit, access to remittances, farm income, access to money for emergency, subsidy from the government and access to savings. Access to and availability of financial resources and stable income support the development of adaptive capacity (Yohe and Tol, 2002; Armitage, 2005; Engle and Lemos, 2007). Most climate change adaptation measures require some level of financial sacrifice, and access to credit/funds can increase farmers' capacity to adopt coping measures to recover from climate change risks. The result revealed that Ginger LZ has the highest score, 0.334, as the current higher market value of the crop contributed for its higher value; whereas, Maize LZ has the least score, 0.247, as this LZ rely on selling green maize which has relatively lower market value as compared with ginger, contributed for its less value.

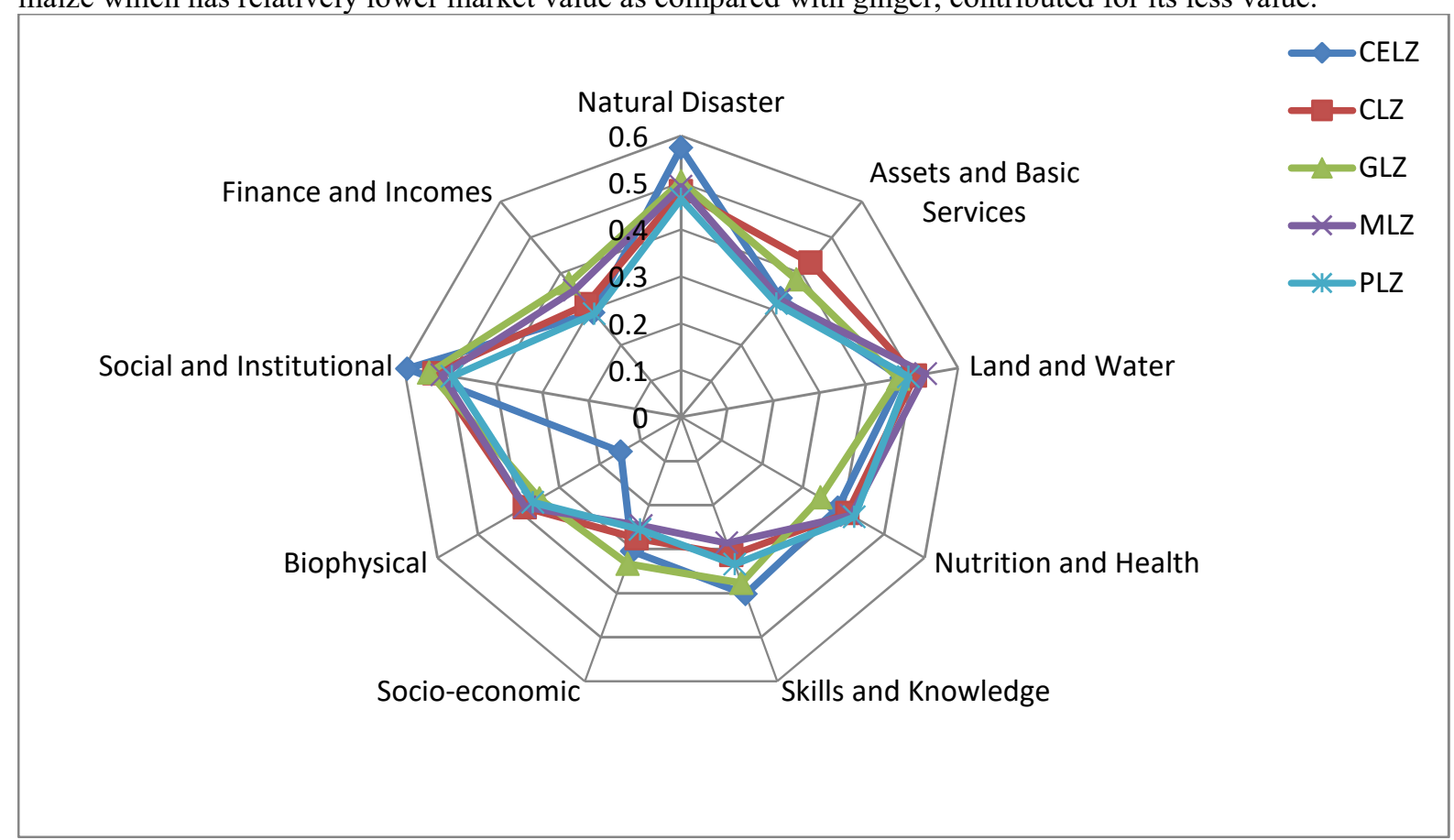

Figure 3: Vulnerability Spider Diagram of the Major Components of LVI

Source: Household survey 
IPCC's Vulnerability Index (LVI-IPCC): Compare and Contrast

The LVI-IPCC was computed by grouping the nine major components into three categories namely; exposure (made up of two major components), sensitivity (one major component) and adaptive capacity (six major components) are represented in the vulnerability table as shown in Table ---. Index values should be interpreted as relative values to be compared within the study sample only. The LVI-IPCC is on a scale from -1 (least vulnerable) to 1 (most vulnerable). The overall LVI-IPCC result shows that Coffee LZ is the highest vulnerable to climate change, whereas, Ginger LZ is the least vulnerable.

Table 3: IPCC Vulnerability Factors

\begin{tabular}{|l|l|l|l|l|l|}
\hline IPCC Contributing Factors to Vulnerability & CELZ & CLZ & GLZ & MLZ & PLZ \\
\hline Exposure & 0.088 & 0.090 & 0.087 & 0.080 & 0.077 \\
\hline Sensitivity & 0.062 & 0.065 & 0.061 & 0.068 & 0.064 \\
\hline Adaptive Capacity & 0.264 & 0.254 & 0.270 & 0.247 & 0.245 \\
\hline LVI-IPCC & -0.1091 & -0.1074 & -0.1119 & -0.1152 & -0.1092 \\
\hline
\end{tabular}

Source: Household survey

Very high exposure coupled with limited adaptive capacity made Coffee LZ as the most vulnerable among the five LZs. In the context of Ginger LZ, very high adaptive capacity and low sensitivity, coupled with medium level exposure to climate change has greatly contributed for its least vulnerability score.

To compare the findings of the research with those researches undertaken agro-ecologically, farmers in midland agro-ecological zone, but with respective specific assets, capabilities and access and ownership of intangible resources, livelihood zones located within the same agro-ecology are both highly vulnerable (Coffee LZ) and less vulnerable (Ginger LZ). On the other hand, Simane et.al., (2016) reported that both farmers in the Dega (Highland) and Kolla (Lowland) agroecological zones were more vulnerable than those in the Weyna Dega (Midland) agroecological zone.
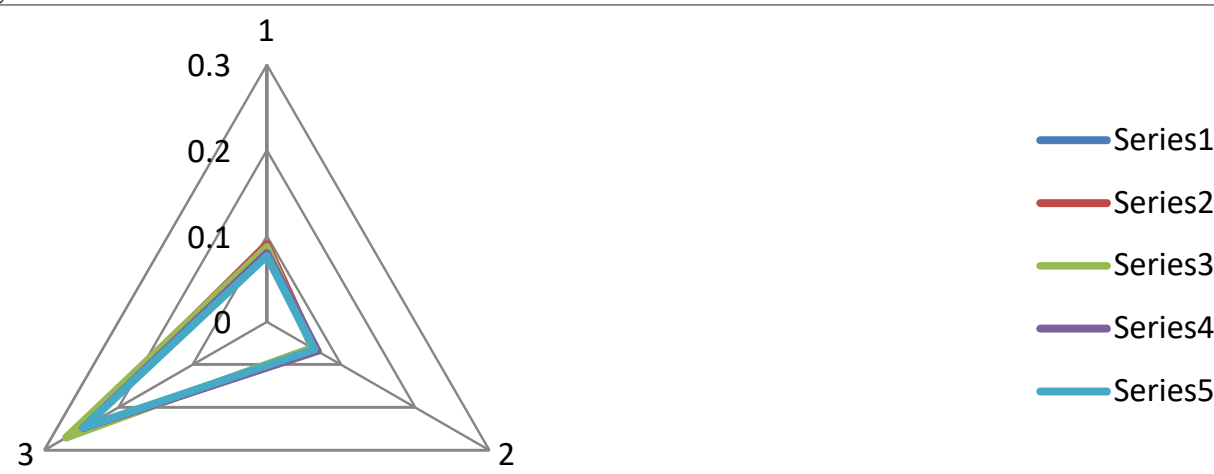

\section{Exposure; 2. Sensitivity; 3. Adaptive Capacity}

Figure 4: Vulnerability Triangle Diagram of LVI-IPCC Contributing Factors Source: Household survey

\subsection{Vulnerability Mapping}

The vulnerability mapping is an important tool that helps to take effective response actions to the adverse impacts of climate change through identification of vulnerable areas. The knowledge of vulnerability to climate change can assist decision makers in recommending adaptation measures and prioritizing resource allocation for specific areas as well as determining investments for adaptation to future impacts of climate change.

\subsection{Exposure Index}

Two components; namely, Frequency of Natural Disaster and Climate Variability and Infrastructure, Assets and Basic Services constitute the exposure contributing factor. The analysis result shows that Coffee LZ has the highest exposure result (0.090); indicating that the LZ has the highest score in terms of Natural Disaster and low score in Assets and Services, whereas, Maize LZ and Pepper LZ have very low levels of the score, the least being that of Pepper LZ, scoring 0.077 and that of Maize LZ is 0.080 , indicating that the LZs have implications in terms of achieving higher results in Natural Disaster and lower score in Assets and Services. On the other hand, Cereal and Enset and Ginger LZs fall under medium level of exposure. 


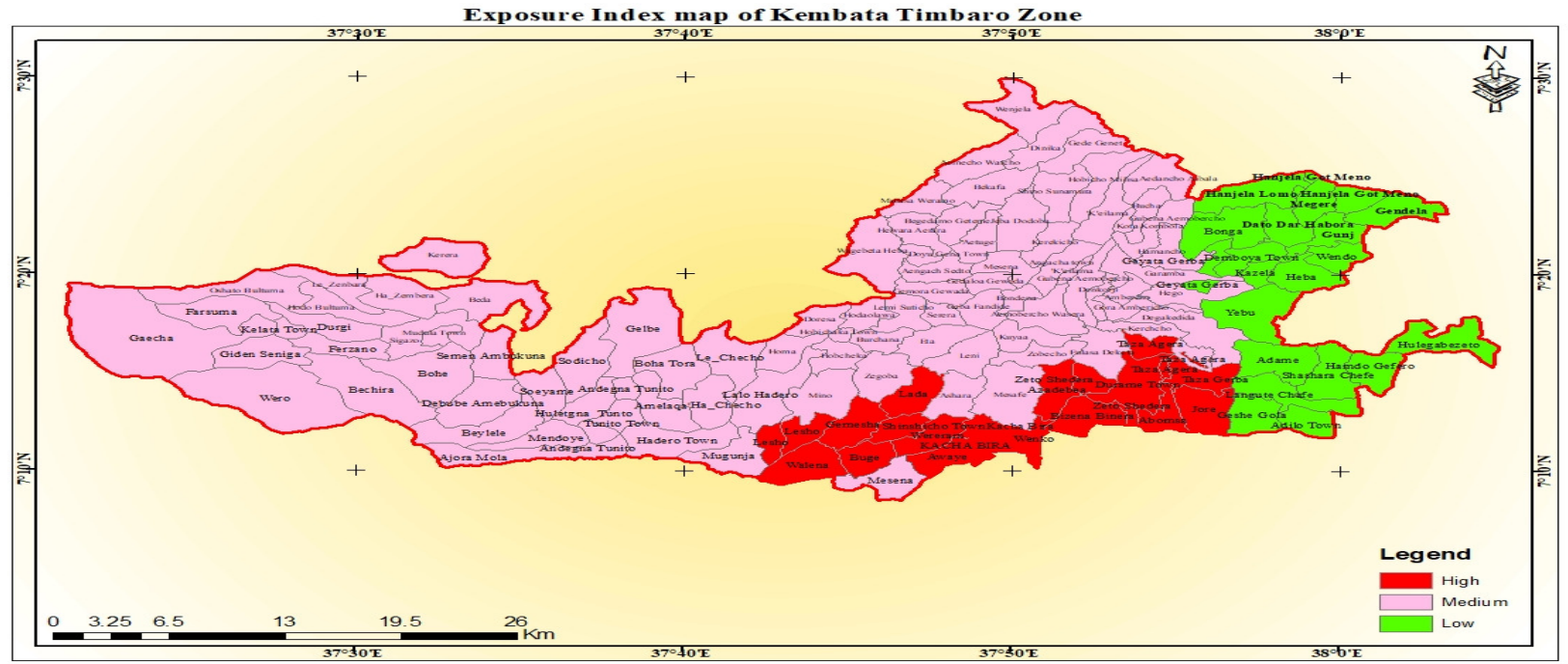

Figure 5: Exposure Index Map

Source: Own construction

\subsubsection{Sensitivity Index}

Results from the sensitivity analyses revealed that Ginger LZ and Cereal and Enset LZs scored 0.061 and 0.062 , respectively, which fall under the low sensitive categories; Ginger LZ is the least sensitive to climate change; whereas, Maize LZ has the highest sensitivity score (0.068). This is because in Maize LZ, the sub-indicators for sensitivity, including less access to water, high effect of climate change on extinction of crop varieties and postharvest loss have contributed for its higher value. The result is in coincidence with the findings of Gebreegziabher, et.al., (2016), which is conducted in four major agro-ecological zones in the Nile Basin of Ethiopia by constructing composite vulnerability indices, indicating that drought-prone highland areas are the most sensitive zone to climate change. The area is characterized by higher frequency of drought, flooding and hailstorms, in addition to high temperature that is increasing over time.

Regarding sensitivity, even though population density is highest in Ginger LZ, the findings indicated that the LZ has the least score in sensitivity. From the generally known trend, agro-ecologically those moisture-sufficient highland areas tend to score least in terms of sensitivity; whereas, drought-prone areas tend to score higher in sensitivity to climate change. In a similar trend, Maize LZ has scored the highest in sensitivity score, which is characterized by higher frequency of drought, flooding and hailstorms, in addition, maximum temperature is increasing in this LZ over time. On the other hand, Pepper LZ and Coffee LZ fall under medium level sensitive LZs, with 0.064 and 0.065 score, respectively.

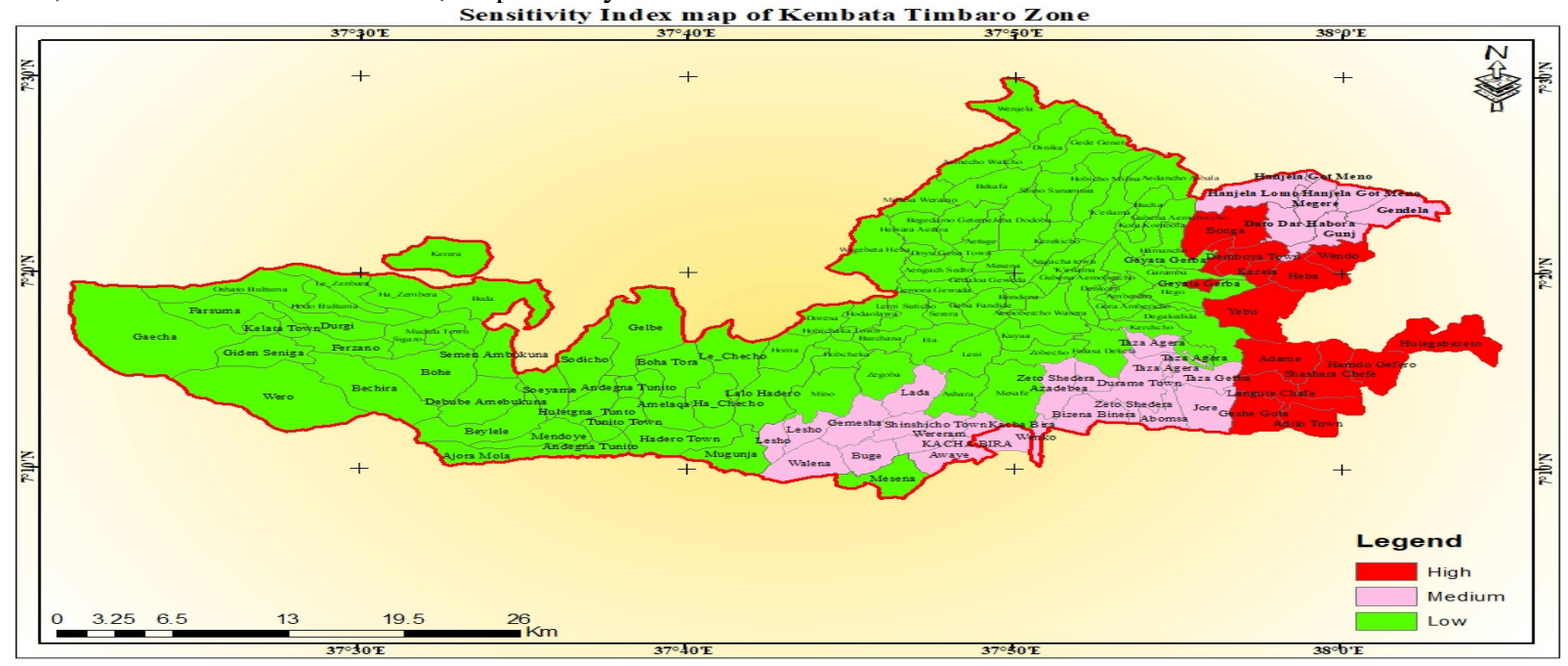

Figure 6: Sensitivity Index Map

Source: Own construction

\subsubsection{Adaptive Capacity Index}

Adaptive capacity is represented in the LVI-IPCC analysis through six major components, namely; Skills and knowledge, Socio-economic, Social and Institutional, Finance and Incomes, Bio-Physical/Environmental and 
Nutritional and Health Status. The analyses of indices for the five LZs indicated that Ginger LZ has the highest score of adaptive capacity, with 0.270 , whereas Pepper LZ has the least adaptive capacity $(0.245)$. The prime factor leading for Ginger LZ's highest adaptive capacity is the highest score in finance and income component, among others. On the other hand, Pepper LZ has the least adaptive capacity (0.245), with fewer score in crop diversification index, less score in educational attainment as indicated in table 3.1., technology adoption and access to social membership, among other sub-components.

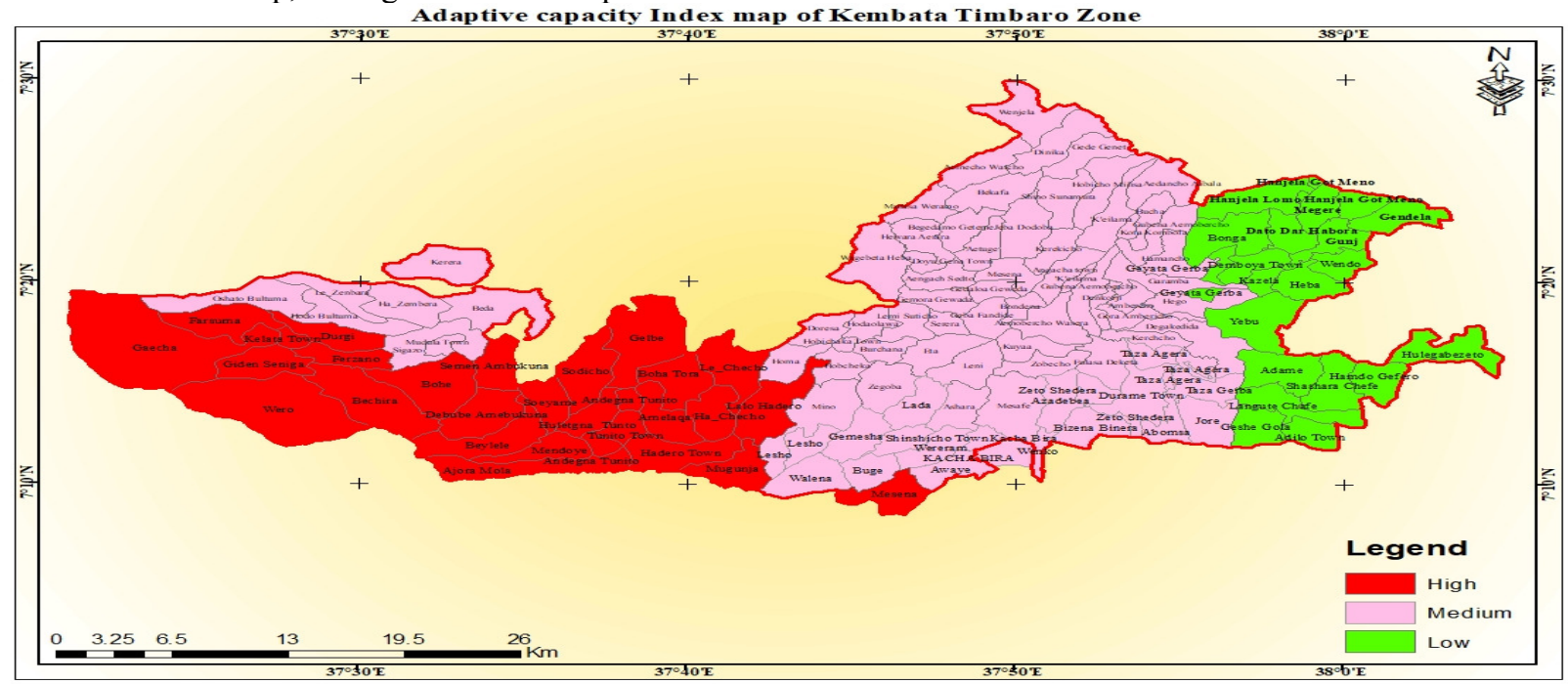

Figure 7: Adaptive Capacity Index Map

Source: Own construction

\subsubsection{Aggregate Vulnerability Index}

The aggregate vulnerability was mapped based on the potential contributing factors that are expressed by exposure, sensitivity, and adaptive capacity. The result implies that a higher adaptive capacity is associated with a lower vulnerability, while a higher potential impact is associated with a higher vulnerability. Contextually, the aggregate vulnerability index map revealed that Coffee LZ is the most vulnerable to adverse impacts of climate change, while Ginger LZ scored the lowest level of vulnerability because of potential low adverse impact and high adaptive capacity. Cereal and Enset and Pepper LZs fall under medium level of vulnerability.

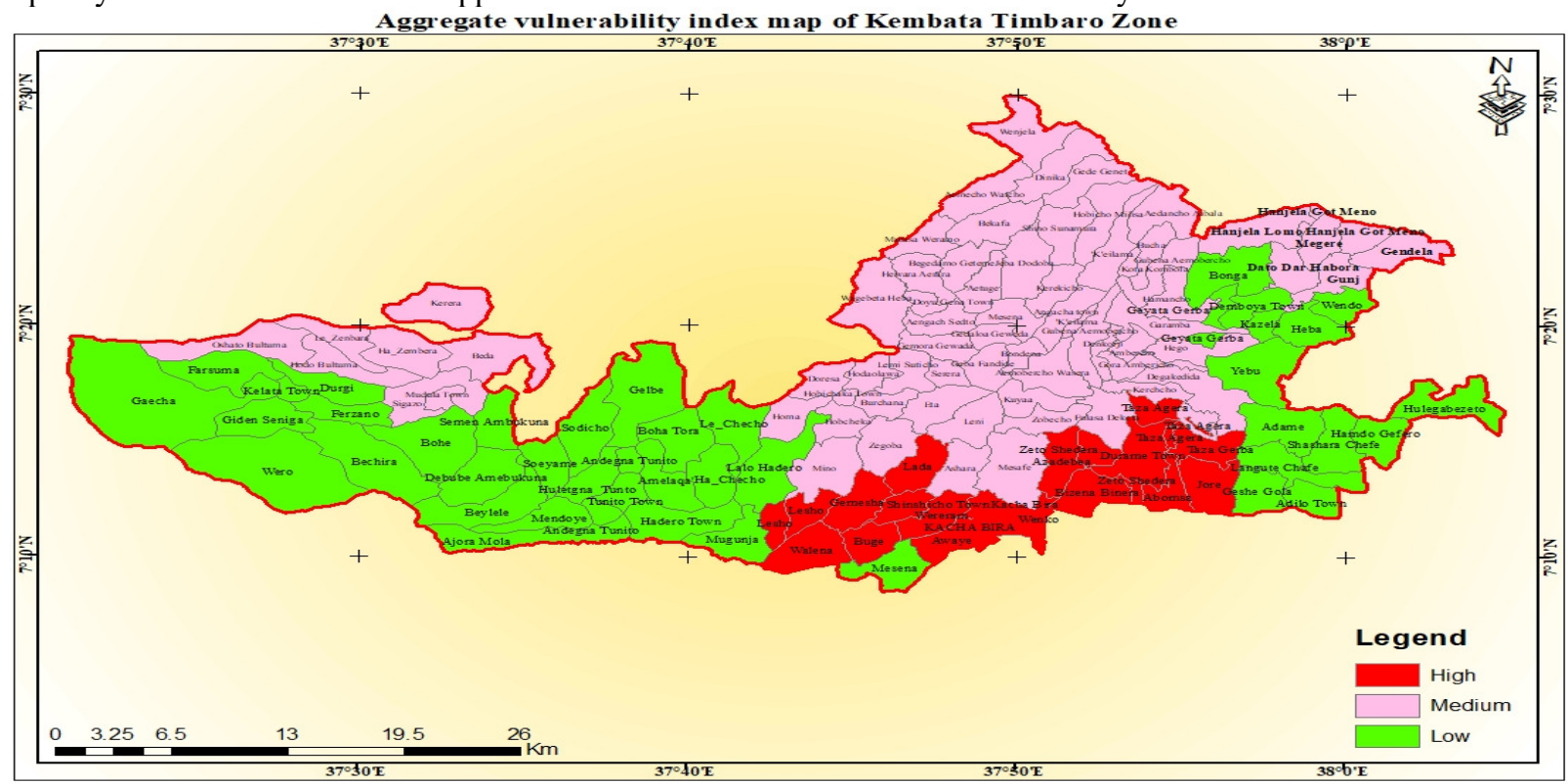

Figure 8: Aggregate Vulnerability Index Map

Source: Household survey

\subsection{Summary}

The chapter analyzed vulnerability of smallholder farmers to climate change and variability in five livelihood zones using the LVI and LVI-IPCC methodologies. Household level data about livelihood capitals and climate related variables were used to develop vulnerability indices and determine vulnerability patterns across the study 
area. Results of the vulnerability assessment confirmed that all the five livelihood zones are vulnerable to climate change. However, in relative terms, Coffee LZ is the most vulnerable to climate change, whereas, Ginger LZ (Agro-ecologically located in midland) is the least vulnerable to climate change. Cereal and Enset and Pepper LZs fall under the medium category of vulnerability level. Assessment of vulnerability is useful to identify and prioritize vulnerable areas and contributing factors for adaptation planning. Therefore, this study can inform policies to deliver better interventions for communities and smallholder farmers at the grassroots level.

Competing interests: The authors declare that they have no competing interests.

Notes

1. The study forms part of the broader research project of $\mathrm{PhD}$ Dissertation "Smallholder Farmers' Vulnerability to Climate Change and their Adaptation Strategies".

2. Smallholder farmers: are understood as 'farmers using predominantly family labour and for whom the farm provides their main source of income and livelihood' (Johansen, Haque, Bell, Thierfelder, \& Esdaile, 2012, p. 19). They are variously described as family farmers, subsistence farmers, poor farmers and peasant farmers. Smallholder farming is characterized by small farm size, low technology and low capitalization (Hameso, 2015).

3. Birr: Ethiopian currency

4. Enset is a long maturity plant, taking about 4-6 years to fully mature; but it is often processed and consumed before full maturity. It requires longer rainy season to flourish.

5. Coffee is a long maturity tree (3-4 years) and once planted and maintained, it can produce for decades. Depending on altitude, coffee beans are harvested between September and January. At lower elevations, harvesting takes place between October and December.

6. Livelihood Zone/s (LZs): Geographical areas within which households (on average) share similar livelihood patterns, i.e. they have access to the same set of food and cash income sources and to the same markets.

\section{References}

Adenew, B. (2006). Effective Aid for Small Farmers in Sub-Saharan Africa: Southern Civil Society Perspectives: Canadian Food Security Policy Group. Addis Ababa, Ethiopia.

Alkire, S., Housseini, B., \& Series, O. S. (2014). Multidimensional Poverty in Sub-Saharan Africa: Levels and Trends. OPHI Working Paper. Vol. 81, 3.

Armitage, Derek (2005). Adaptive capacity and community-based natural resource management. Environmental Management 35 (6): 703-715.

CSA (Central Statistical Agency), (2013). "Population Projection of Ethiopia for All Regions at Woreda Level from 2014 - 2017', The Federal Democratic Republic of Ethiopia, Addis Ababa.

Deresa TT, Hassan RM, Ringler C., (2011). Perception of and adaptation to climate change by farmers in the Nile Basin of Ethiopia. Journal of Agricultural Science 149(1):23-31.

DPPC (Disaster Prevention and Preparedness Commission), (2005b). SNNPR Livelihood Profile: HadiyaKambata Cereal and Enset Zone Report, Addis Ababa: LIU.

DRMFSS (Disaster Risk Management and Food Security Sector), (2010). An Atlas of Ethiopian Livelihoods, Addis Ababa: MOARD.

Engle, N.L. and Lemos, M.C. (2010). Unpacking governance: Building adaptive capacity to climate change of river basins in Brazil. Global Environmental Change 20, 4-13.

FAO and ILO, (2009). The Livelihood Assessment Tool-kit: Analysing and responding to the impact of disasters on the livelihoods of people Volume 1: Methodological and Conceptual Overview [First Edition] FAO and ILO.

Gbetibouo, G. A., Ringler, C., \& Hassan, R. (2010, August). Vulnerability of the South African farming sector to climate change and variability: an indicator approach. In Natural Resources Forum (Vol. 34, No. 3, pp. 175187). Oxford, UK: Blackwell Publishing Ltd.

Gebreegziabher Z., Mekonnen A., Deribe R., Boka, J., and Abera S., (2016). Mapping Vulnerability to Climate Change of the Farming Sector in the Nile Basin of Ethiopia: A Micro-level Perspective. Environment for Development: Discussion Paper Series. EfD DP 16-19.

Hahn, M., A. Reiderer, and S. Foster, (2009). The Livelihood Vulnerability Index: A Pragmatic Approach to Assessing Risks from Climate Variability and Change: A Case Study in Mozambique. Global Environmental Change 19: 74-88.

Intergovernmental Panel on Climate Change (IPCC). (2014). Climate change 2014: Impacts, adaptation, and vulnerability. Part B: Regional aspects. Contribution of working group II to the fifth assessment report of the Intergovernmental Panel on Climate Change (IPCC). Cambridge University Press.

Kothari, C.R. (2004). Research Methodology: Methods and Techniques. 2nd Edition, p. 179. New Age International Publishers, New Delhi.

Niang, I., Ruppel, O.C., Abdrabo, M.A., Essel, A., Lennard, C., Padgham, J. and Urquhart, P. (2014). Africa. In: 
Climate Change 2014: Impacts, Adaptation, and Vulnerability. Part B: Regional Aspects. Contribution of Working Group II to the Fifth Assessment Report of the Intergovernmental Panel on Climate Change. Cambridge, UK: Cambridge University Press.

Ondiege, P., Moyo, J. M., \&Verdier-Chouchane, A. U. D. R. E. Y. (2013). Developing Africa's Infrastructure for Enhanced Competitiveness. In World Economic Forum (eds), The Africa Competitiveness Report.

Seaman, J. A., Sawdon, G. E., Acidri, J., \& Petty, C. (2014). The Household Economy Approach. Managing the impact of climate change on poverty and food security in developing countries. Climate risk management, 4 , 59-68.

Simane B., Benjamin F. Zaitchik, and Jeremy D. Foltz, (2016). "Agroecosystem specific climate vulnerability analysis: application of the livelihood vulnerability index to a tropical highland region." Mitigation and Adaptation Strategies for Global Change 21: 39-65.

Yohe, G.; Tol, R. (2002). Indicators for social and economic coping capacity-moving toward a working definition of adaptive capacity. Glob. Environ. Chang. 12, 25-40.

Annex:

\begin{tabular}{|c|c|c|c|c|c|}
\hline & Capitals/Disaster & $\begin{array}{l}\text { Major } \\
\text { components } \\
\text { and Assigned } \\
\text { Weights } \\
\end{array}$ & Sub-indicators & Hypothetical relationship & $\begin{array}{l}\text { Assigned } \\
\text { Weight for } \\
\text { Sub- } \\
\text { indicators } \\
\end{array}$ \\
\hline \multirow{13}{*}{ Exposure } & \multirow{4}{*}{$\begin{array}{l}\text { Natural Disaster } \\
55\end{array}$} & \multirow{4}{*}{$\begin{array}{l}\text { Frequency of } \\
\text { Natural } \\
\text { Disaster and } \\
\text { Climate } \\
\text { Variability } \\
\text { (9) }\end{array}$} & $\begin{array}{l}\text { Frequency of natural } \\
\text { disaster }\end{array}$ & $\begin{array}{l}\text { The more frequency in natural } \\
\text { disaster, the higher exposure }\end{array}$ & 40 \\
\hline & & & $\begin{array}{l}\text { Increase in average } \\
\text { annual temperature } \\
\text { between } \\
1984-2017\end{array}$ & $\begin{array}{l}\text { The more increase in temperature, } \\
\text { the higher exposure }\end{array}$ & 20 \\
\hline & & & $\begin{array}{l}\text { Increase in average } \\
\text { annual rainfall duration } \\
\text { between 1984-2017 }\end{array}$ & $\begin{array}{l}\text { The more increase in rainfall, the } \\
\text { higher exposure }\end{array}$ & 20 \\
\hline & & & $\begin{array}{l}\text { Vulnerability to the } \\
\text { incidence of drought }\end{array}$ & $\begin{array}{l}\text { The more vulnerability to the } \\
\text { incidence of drought, the higher } \\
\text { exposure }\end{array}$ & 20 \\
\hline & \multirow{9}{*}{$\begin{array}{l}\text { Physical } \\
45\end{array}$} & \multirow{9}{*}{$\begin{array}{l}\text { Infrastructure, } \\
\text { assets and basic } \\
\text { services } \\
\text { (11) }\end{array}$} & $\begin{array}{l}\text { Access to all weather } \\
\text { roads }\end{array}$ & $\begin{array}{l}\text { The more access to all weather roads, } \\
\text { the less exposure }\end{array}$ & 15 \\
\hline & & & $\begin{array}{l}\text { Access to veterinary } \\
\text { services }\end{array}$ & $\begin{array}{l}\text { The more access to veterinary } \\
\text { services, the less exposure }\end{array}$ & 12 \\
\hline & & & Farm size & $\begin{array}{l}\text { The higher farm size, the less } \\
\text { exposure }\end{array}$ & 30 \\
\hline & & & Livestock ownership & $\begin{array}{l}\text { The higher livestock ownership, the } \\
\text { less exposure }\end{array}$ & 10 \\
\hline & & & $\begin{array}{l}\text { Access to climate } \\
\text { information }\end{array}$ & $\begin{array}{l}\text { The more access to climate } \\
\text { information, the less exposure }\end{array}$ & 10 \\
\hline & & & $\begin{array}{l}\text { Access to early warning } \\
\text { information }\end{array}$ & $\begin{array}{l}\text { The more access to early warning } \\
\text { information, the less exposure }\end{array}$ & 8 \\
\hline & & & Type of house & $\begin{array}{l}\text { The more access to home with } \\
\text { galvanized, cement and hut } \\
\text { (thatched), the less exposure }\end{array}$ & 6 \\
\hline & & & $\begin{array}{l}\text { Ownership of pack } \\
\text { animals (like donkey) for } \\
\text { transport }\end{array}$ & $\begin{array}{l}\text { The more access to pack animals } \\
\text { (transport), the less exposure }\end{array}$ & 4 \\
\hline & & & Ownership of plough & $\begin{array}{l}\text { The more access to production } \\
\text { means like plough, the less exposure }\end{array}$ & 5 \\
\hline \multirow[t]{6}{*}{ Sensitivity } & \multirow[t]{6}{*}{ Natural } & \multirow{6}{*}{$\begin{array}{l}\text { Crop Land and } \\
\text { water } \\
\text { (13) }\end{array}$} & Land productivity & $\begin{array}{l}\text { The more percent of fertile land, the } \\
\text { lesser sensitivity }\end{array}$ & 26 \\
\hline & & & Access to grazing land & $\begin{array}{l}\text { The more access to grazing land, the } \\
\text { lesser sensitivity }\end{array}$ & 15 \\
\hline & & & $\begin{array}{l}\text { Access to animal } \\
\text { forage/pasture }\end{array}$ & $\begin{array}{l}\text { The more access to animal forage, } \\
\text { the lesser sensitivity }\end{array}$ & 17 \\
\hline & & & Access to water & $\begin{array}{l}\text { The more access to water (Potable } \\
\text { and Irrigation), the lesser sensitivity }\end{array}$ & 15 \\
\hline & & & Effect of post-harvest loss & $\begin{array}{l}\text { The higher post-harvest loss, the } \\
\text { higher sensitivity }\end{array}$ & 12 \\
\hline & & & $\begin{array}{l}\text { Effect of extinction of } \\
\text { crop varieties }\end{array}$ & $\begin{array}{l}\text { The higher number of extinction of } \\
\text { crop varieties, the higher sensitivity }\end{array}$ & 15 \\
\hline \multirow[t]{3}{*}{$\begin{array}{l}\text { Adaptive } \\
\text { Capacity }\end{array}$} & \multirow[t]{3}{*}{$\begin{array}{l}\text { Human } \\
40\end{array}$} & \multirow{2}{*}{$\begin{array}{l}\text { Nutritional and } \\
\text { health status } \\
\text { (8) }\end{array}$} & Access to Food & $\begin{array}{l}\text { The more access to food, the more } \\
\text { adaptive capacity }\end{array}$ & 60 \\
\hline & & & Health status & $\begin{array}{l}\text { The higher access to health, the more } \\
\text { adaptive capacity }\end{array}$ & 40 \\
\hline & & $\begin{array}{l}\text { Skills and } \\
\text { knowledge }\end{array}$ & $\begin{array}{l}\text { Educational attainment of } \\
\text { household head }\end{array}$ & $\begin{array}{l}\text { The more educated household head, } \\
\text { the more adaptive capacity }\end{array}$ & 35 \\
\hline
\end{tabular}




\begin{tabular}{|c|c|c|c|c|}
\hline Capitals/Disaster & $\begin{array}{l}\text { Major } \\
\text { components } \\
\text { and Assigned } \\
\text { Weights }\end{array}$ & Sub-indicators & Hypothetical relationship & $\begin{array}{l}\text { Assigned } \\
\text { Weight for } \\
\text { Sub- } \\
\text { indicators } \\
\end{array}$ \\
\hline & \multirow[t]{2}{*}{ (18) } & Skill upgrade & $\begin{array}{l}\text { The more diversified skill (Training } \\
\text { access), the more adaptive capacity }\end{array}$ & 25 \\
\hline & & Technology adoption & $\begin{array}{l}\text { The more access to technology, the } \\
\text { more adaptive capacity }\end{array}$ & 40 \\
\hline & \multirow[t]{3}{*}{$\begin{array}{l}\text { Socio-economic } \\
\text { (10) }\end{array}$} & Farming experience & $\begin{array}{l}\text { The more farming experience in } \\
\text { years, the more adaptive capacity }\end{array}$ & 35 \\
\hline & & Dependency ratio & $\begin{array}{l}\text { The more dependency ratio, the less } \\
\text { adaptive capacity }\end{array}$ & 30 \\
\hline & & Off-farm activity & $\begin{array}{l}\text { The more access to off-farm activity, } \\
\text { the more adaptive capacity }\end{array}$ & 35 \\
\hline \multirow[t]{5}{*}{$\begin{array}{l}\text { Natural } \\
20\end{array}$} & \multirow[t]{5}{*}{$\begin{array}{l}\text { Bio-Physical } \\
\text { /Environmental } \\
\text { (6) }\end{array}$} & $\begin{array}{l}\text { Land protected from } \\
\text { degradation }\end{array}$ & $\begin{array}{l}\text { The more percent of degraded land, } \\
\text { the less adaptive capacity (Land } \\
\text { degradation index) }\end{array}$ & 15 \\
\hline & & Vegetation cover & $\begin{array}{l}\text { The more vegetation cover, the } \\
\text { higher adaptive capacity }\end{array}$ & 15 \\
\hline & & $\begin{array}{l}\text { Slope (topography) of } \\
\text { cultivated land }\end{array}$ & $\begin{array}{l}\text { The more percentage of good } \\
\text { topography for cropping, the higher } \\
\text { adaptive capacity }\end{array}$ & 20 \\
\hline & & Access to irrigation & $\begin{array}{l}\text { The more access to irrigation, the } \\
\text { higher adaptive capacity }\end{array}$ & 30 \\
\hline & & $\begin{array}{l}\text { Crop } \quad \text { Diversification } \\
\text { Index }\end{array}$ & $\begin{array}{l}\text { More crop diversity, higher will be } \\
\text { adaptive capacity }\end{array}$ & 20 \\
\hline \multirow{6}{*}{ Social } & \multirow{6}{*}{$\begin{array}{l}\text { Social and } \\
\text { Institutional } \\
(16)\end{array}$} & $\begin{array}{l}\text { Access to social } \\
\text { membership }\end{array}$ & $\begin{array}{l}\text { The more access to social } \\
\text { membership, the higher adaptive } \\
\text { capacity }\end{array}$ & 25 \\
\hline & & Cultural connectivity & $\begin{array}{l}\text { The more access to cultural } \\
\text { connectivity, the higher adaptive } \\
\text { capacity }\end{array}$ & 22 \\
\hline & & Trust and mutual support & $\begin{array}{l}\text { The more social help at times of } \\
\text { shocks (Covariate and idiosyncratic } \\
\text { shocks), the higher adaptive capacity }\end{array}$ & 10 \\
\hline & & $\begin{array}{l}\text { Local institutional } \\
\text { support }\end{array}$ & $\begin{array}{l}\text { The more access to get support from } \\
\text { local institutions (iddir, equb, etc), } \\
\text { the higher adaptive capacity }\end{array}$ & 8 \\
\hline & & $\begin{array}{l}\text { Access to indigenous } \\
\text { knowledge }\end{array}$ & $\begin{array}{l}\text { The more access to indigenous } \\
\text { Knowledge (coping and adaptation), } \\
\text { the higher adaptive capacity }\end{array}$ & 15 \\
\hline & & $\begin{array}{l}\text { Traditional Weather } \\
\text { Prediction }\end{array}$ & $\begin{array}{l}\text { The more access to get traditional } \\
\text { weather prediction, the higher } \\
\text { adaptive capacity }\end{array}$ & 20 \\
\hline \multirow[t]{6}{*}{ Financial } & \multirow{6}{*}{$\begin{array}{l}\text { Finance and } \\
\text { incomes } \\
\text { (9) }\end{array}$} & Access to credit & $\begin{array}{l}\text { The more access to credit services, } \\
\text { the higher adaptive capacity }\end{array}$ & 15 \\
\hline & & Access to remittances & $\begin{array}{l}\text { The more access to remittance, the } \\
\text { higher adaptive capacity }\end{array}$ & 17 \\
\hline & & Access to savings & $\begin{array}{l}\text { The more access to get saving } \\
\text { services, the higher adaptive } \\
\text { capacity }\end{array}$ & 9 \\
\hline & & $\begin{array}{l}\text { Access to money for } \\
\text { emergency }\end{array}$ & $\begin{array}{l}\text { The more access to get money for } \\
\text { emergency, the higher adaptive } \\
\text { capacity }\end{array}$ & 10 \\
\hline & & $\begin{array}{l}\text { Subsidy from the } \\
\text { government }\end{array}$ & $\begin{array}{l}\text { The more access to get subsidy from } \\
\text { the government, the higher adaptive } \\
\text { capacity }\end{array}$ & 8 \\
\hline & & Farm income & $\begin{array}{l}\text { The higher farm income, the higher } \\
\text { adaptive capacity }\end{array}$ & 25 \\
\hline
\end{tabular}

